\title{
The constitution of the Russian Federation and constitutional identity in the context of global changes
}

\author{
Evgeniy Vladimirovich Kirichek ${ }^{1 *}$, Eduard Anatolievich Kononov ${ }^{2}$, and Golib Nurullo \\ Kodirzoda ${ }^{3}$ \\ ${ }^{1}$ Academy of Management of the MIA of Russia, Teaching and Methodological Department, \\ Moscow, Russia \\ ${ }^{2}$ Far Eastern Branch of Russian State University of Justice, Department of State and Legal \\ Disciplines, Khabarovsk, Russia \\ ${ }^{3}$ Academy of the Ministry of Internal Affairs of the Republic of Tajikistan Department of State Legal \\ Disciplines, Faculty No. 2, Dushanbe, Tajikistan
}

\begin{abstract}
Today we are witnesses and participants in a historic event that is very important for Russia - preparation and adoption of amendments to the Constitution of the Russian Federation, reflecting both a legal identity and a vast long-term experience of the constitutional development of the Russian state with due consideration to the opinion of various strata of the population and extensive public discussion. Goal of the research is to show a special role of the Constitution of the Russian Federation from the position of its supremacy in combination with the doctrine of constitutional identity, which is essentially a trend of modern globalization processes, based on the analysis of doctrinal and practical issues, laws and regulations, decisions of the Constitutional Court of the Russian Federation, the European Court of Human Rights, and statistical data. The methodological basis of the research consists in the application of both general scientific and special methods developed in jurisprudence. During the research, the following methods of scientific knowledge played a special role: dialectical, historical, comparative law, statistical, logical, etc. A number of conclusions were drawn concerning, on the one hand, the development of a legal potential of the Constitution of the Russian Federation being a determining vector in preventing socio-political destabilization, and on the other hand, constitutional identity, in the broadest sense shown in the desire to know and formulate the own national, religious and other identities, to follow traditional family values, etc., and at the state level - prevention of violation of territorial integrity, state sovereignty, acknowledgement of constitutional and legal identity of the state.
\end{abstract}

Keywords: constitution, constitutional identity, Constitutional Court of the Russian Federation, European Court of Human Rights

"Corresponding author: kirichek79@yandex.ru 


\section{Introduction}

As far as is known, the adoption of the Constitution of the Russian Federation resulted from significant changes at the time. This also holds true for the modern period, when modernization of various spheres of public and state life resulted in serious amendments to the Constitution, approved in the course of all-Russian voting on the $1^{\text {st }}$ of July 2020 effective from the $4^{\text {th }}$ of July 2020. This is a serious step towards ensuring human and civil rights and democratic freedoms. The Constitution 1993, for a rather short period of its existence, was in difficult conditions and against all the odds managed to withstand the onslaught of global transformations.

Are there any drawbacks in our Constitution? We may say, of course, there are, but it depends on what we mean under the drawbacks. Paradoxically, throughout the entire period of the Constitution of the Russian Federation 1993, on various platforms, one has to hear opinions about the imperfection of some of its provisions and, as a result, numerous proposals for their correction. Probably there is nothing wrong with that. Selective changes of the constitutional text are quite acceptable, but on the whole, the deep conceptual meaning of the main text allows for its adaptation to the social and legal reality within the doctrine of the "living constitution". All of it enables, without deformation of the legal meaning of the text, to determine its true meaning for the regulation of relevant social relations. This is the approach that the Constitutional Court of the Russian Federation uses in its activities.

The development of a legal potential of the Constitution of the Russian Federation should be a determining vector in preventing socio-political destabilization. The drive to profound constitutional changes seems to be an extensive direction of movement, which can inevitably bring about a change in the course of events or even turn their development back. And, thoughts that the quality of life depends only on some legal regulations seem to be imperfect, superficial, idealistic or even naive.

The Constitution cannot be taken only as a result of social compromise, since the need for it, and therefore for profound constitutional changes, may arise at any time. The main provisions of the Constitution contain the potential for the prospective development of our country in the future, which is a defining characteristic of such legal feature of the Constitution as perspectivity. It is important to respond to challenges, identify socially negative trends and find ways out of the current situation, including legal forms, in due time.

\section{Results}

As evidenced in practice, the greatest impatience and tension in Russian society is observed due to many unsolved socio-economic challenges related to excessive social stratification (if in 2015 the poor/rich ratio was $66 \% / 56 \%$, then in 2020 it was $78 \% / 65 \%$, respectively [1]), the pension level, unemployment (as of September 2020, 6.3\% or 4.8 million people), etc. [2]. This situation is aggravated by the natural fatigue of the population because of continuous reforms. It shows that we are still far from the full-fledged implementation of the provisions of the Constitution related to the development of a social state.

The solution to these and many other problems is found in the implementation of a set of measures aimed at ensuring socio-economic rights in such a way that citizens really feel that they belong to a multinational public united by a common destiny on their land, as follows from the text of the preamble to the Constitution of the Russian Federation.

In this sense, it is reasonable to talk about constitutional identity, which is, in fact, a trend in modern globalization processes. At that, in the broadest sense, it is shown in the desire to know and formulate the own national, religious and other identities, to follow traditional 
family values, etc., and at the state level - prevention of violation of territorial integrity, state sovereignty, acknowledgement of constitutional and legal identity of the state.

The term "constitutional identity" (identical to something (somebody), coincident with something (somebody)) has firstly appeared in the legal practice of Russia in decisions of the Constitutional Court of the Russian Federation. And this is natural, since it is the bodies of constitutional control, including foreign states, use the doctrine of constitutional identity to consider the hardest cases.

In the national constitutional and legal science, this term is defined in different ways. Some authors consider it as a complex systemic phenomenon, including the characteristics of elements of the form of the state, constitutional norms, principles, guarantees, etc. [3] or as a holistic, universal, integrating category that occupies an important place in the system of values, reflecting peculiarities of the constitutional order of the state, its legal realities, degree of identity of the legal system of the state [4], and other authors consider it as a set of constitutional peculiarities related to states, enabling to distinguish them from other states [5]. Moreover, given the similarity of legal norms, their interpretation and, accordingly, the perception by the subjects of implementation of the law may differ significantly. It means that there are no and cannot be absolutely similar constitutional identities in different states [6].

According to G.A. Gadzhiev, the concept of constitutional identity means, first of all, the non-textual perception of constitutional changes that falls within the frames of modern hermeneutics [7].

A.A. Klishas, speaking of continuity and dynamism of constitutional development, defines constitutional identity as a principle requirement to a new regulation. In his opinion, it is reflected in real social practice, manifested in laws and regulations or in newly emerging social relations [5].

The ideas of constitutional identity are not alien to foreign jurisprudence [8-12]. For example, a French jurist $M$. Troper suggests considering constitutional identity through a lens of essential principles that differ from other norms of the constitution and have a special protective property [13].

Special attention should be paid to the position of the Constitutional Court of the Russian Federation, which refers "national norms on fundamental rights, as well as the norms on foundations of the constitutional order, which guarantee these rights" to the basic elements of constitutional identity [14].

In the constitutional and legal sphere, the problem of "exaltation" of the so-called supranational bodies, such as the European Court of Human Rights (hereinafter - the ECHR), which, using their status and active position, are capable of adjusting the convention system, is gaining ground. Minimization of influence of the member states on the ECHR, on the one hand, is a kind of guarantee of its independence, but on the other hand, it pulls it away from the urgent needs and realities typical for national states. All of this enables to speak about certain restrictions in the activities of the ECHR, which do not allow it to step out of line. It is important to remember that the ECHR operates within the limits of its own margin of appreciation, while national states are guided by their own limits of compliance directly arising from the wording of their own constitutions based on their own understanding of national constitutional identity. The effectiveness of the norms of the Convention for the Protection of Human Rights and Fundamental Freedoms in the Russian constitutional legal order depends largely on the extent, to which the ECHR is ready to perceive and respect national constitutional identity [15]. 


\section{Discussion and conclusion}

1. Now it must be admitted that the doctrine of constitutional identity requires in-depth development. One thing is clear that it serves as a kind of "watershed" between the desired changes in the internal constitutional legal order and the principles that states, recognizing the unconditional jurisdiction of supranational bodies, are obliged to follow [16]. Russia, evidently, should move along a path that would meet the expectations of the society and the ideas of rights and freedoms, their inalienability and justice.

2. Desire of Russia to comply with the status of a social state makes public authorities responsible for ensuring a high level of well-being for our citizens. Here, constitutional identity manifests itself, when the national legislation provides more extended social guarantees in comparison with the international one, which evidences the priority of its application.

3. The priority of the provisions of the Constitution of the Russian Federation over the norms of international law is obvious and follows from its concept as a legislative act of the highest legal force exhibiting the property of supremacy. This does not mean that the doctrine of constitutional identity in any way denies the very possibility of international regulation. On the contrary, it enables to develop a balanced course that combines the mechanisms of national and supranational regulation.

4. In its progressive state legal development Russia is focused, first of all, on ensuring of, on the one hand, a national sovereignty, and, on the other hand, undertaken international commitments. In this regard, the amendments to the Constitution of the Russian Federation 2020, defining its priority position over the international acts, will enable Russia, taking into account the national constitutional and legal specifics, to prevent implementation of the norms of the international law that contradict the Constitution of the Russian Federation.

\section{References}

1. A. Chetverikova, Rossiyskaya gazeta 56(8110) (2020)

2. Zanyatost i bezrabotitsa v Rossiiskoi Federatsii v avguste 2020 goda [Employment and unemployment in the Russian Federation in August 2020]. Accessed on: March 23, 2021. [Online]. Available: https://rosstat.gov.ru/bgd/free/B04_03/IssWWW.exe/Stg/d05/181.htm

3. S.P. Chigrinov, J. Foreign Legisl. and Comparat. Law 3, 36 (2016)

4. D.A. Podolyan, North Cauc. Leg. Vestnik 4, 98 (2017)

5. A.A. Klishas, Rossiyskaya gazeta 28(8082) (2020)

6. V.D. Zorkin, Constit. Just. J. 4, 10 (2017)

7. G.A. Gadzhiev, Judge 12, 33 (2017)

8. E. Cloots, Netherlands J. Leg. Philos. 2, (2016). https://doi.org/10.5553/NJLP/.000049

9. A. Manasyan, Law. J. Higher Sch. Ec. 3, 81-98 (2018). https://doi.org/10.17323/20728166.2018.3.81.98

10. M. Polzin, German Law J. 18(7), 1595-1616 (2017). https://doi.org/10.1017/S2071832200022458

11. M. Rosenfeld, The Identity of the Constitutional Subject: Selfhood, Citizenship, Culture and Community (New York, 2010)

12. M. Tushnet, Int. J. Constit. Law 8(3), 671-676 (2010). https://doi.org/10.1093/icon/moq025 
13. M. Troper, Behind the Constitution? The Principle of Constitutional Identity in France, in A. Sajo, R. Uitz (eds.), Constitutional Topography: Values and Constitutions, 2, 11 (2010)

14. Postanovlenie Konstitutsionnogo Suda RF ot 14 iyulya 2015 g. № 21-P “Po delu o proverke konstitutsionnosti polozhenii stati 1 Federalnogo zakona "O ratifikatsii Konventsii o zashchite prav cheloveka i osnovnykh svobod i Protokolov k nei”, punktov 1 i 2 stati 32 Federalnogo zakona "O mezhdunarodnykh dogovorakh Rossiiskoi Federatsii”, chastei pervoi i chetvertoi stati 11, punkta 4 chasti chetvertoi stati 392 Grazhdanskogo protsessualnogo kodeksa Rossiiskoi Federatsii, chastei 1 i 4 stati 13, punkta 4 chasti 3 stati 311 Arbitrazhnogo protsessualnogo kodeksa Rossiiskoi Federatsii, chastei 1 i 4 stati 15, punkta 4 chasti 1 stati 350 Kodeksa administrativnogo sudoproizvodstva Rossiiskoi Federatsii i punkta 2 chasti chetvertoi stati 413 Ugolovnoprotsessualnogo kodeksa Rossiiskoi Federatsii v svyazi s zaprosom gruppy deputatov Gosudarstvennoi Dumy" [Ruling of the Constitutional Court of the Russian Federation dated 14 July 2015 \# 21- $\Pi$ "On the constitutionality of provisions of the article 1 of the Federal Law "On ratification of the Convention for the protection of human rights and fundamental freedoms and Protocols thereto", clauses 1 and 2 of the article 32 of the Federal Law "On international treaties of the Russian Federation", part 1 and 4 of the article 11, clause 4 of part 4 of the article 392 of the Civil Procedure Code of the Russian Federation, part 1 and 4 of the article 13, clause 4 of part 3 of the article 311 of the Arbitration Procedure Code of the Russian Federation, part 1 and 4 of the article 15 , clause 4 of part 1 of the article 350 of the Code of Administrative Judicial Procedure of the Russian Federation and clause 2 of part 4 of the article 413 of the Russian Federation Code of Criminal Procedure following the request of a group of deputies of the State Duma"] Col. of Legisl. Acts RF 30, 4658 (2015)

15. Postanovlenie Konstitutsionnogo Suda RF ot 19 yanvarya 2017 g. № 1-P “Po delu o razreshenii voprosa o vozmozhnosti ispolneniya v sootvetstvii s Konstitutsiei Rossiiskoi Federatsii postanovleniya Evropeiskogo Suda po pravam cheloveka ot 31 iyulya 2014 goda po delu "OAO "Neftyanaya kompaniya "YuKOS" protiv Rossii" v svyazi s zaprosom Ministerstva yustitsii Rossiiskoi Federatsii" [Ruling of the Constitutional Court of the Russian Federation dated 19 January 2017 \# 1-П “On adjudication of the question of enforcement according to the Constitution of the Russian Federation of judgement of the European Court of Human Rights dated 31 July 2014 referred to the case "OJSC "Yukos Oil Company" v. Russia" following the request of the Ministry of Justice of the Russian Federation] Col. Legisl. Acts RF 5, 866 (2017)

16. V.D. Zorkin, Rossiyskaya gazeta 226(7689) (2018) 